DOI: $10.18276 /$ sip.2017.48/1-02

\title{
Karolina Beyer*
}

Uniwersytet Szczeciński

\section{KAPITAŁ RYNKOWY W KSZTAŁTOWANIU KAPITAŁU INTELEKTUALNEGO}

\section{STRESZCZENIE}

Kapitał rynkowy obok kapitału ludzkiego i organizacyjnego jest jednym z elementów kapitału intelektualnego. Sukces współczesnych przedsiębiorstw uzależniony jest od właściwego i efektywnego zarządzania kapitałem intelektualnym, dlatego niezbędne jest zrozumienie istoty poszczególnych jego elementów. Kapitał rynkowy określa się jako relacje z otoczeniem zewnętrznym, głównie z klientami, ale także dostawcami, konkurentami i partnerami. $Z$ kapitałem tym powiązane są również m.in. renoma przedsiębiorstwa, image czy lojalność klientów. Kapitał rynkowy tworzy wartość przedsiębiorstwa dzięki właściwym kontaktom z jego otoczeniem. Wynika on z zaangażowania kapitału ludzkiego, który jest wspomagany przez kapitał organizacyjny.

Artykuł ma charakter teoretyczny, a jego głównym celem jest zaprezentowanie istoty kapitału rynkowego oraz wybranych jego elementów składowych z uwzględnieniem ich roli w kształtowaniu kapitału intelektualnego organizacji.

Słowa kluczowe: kapitał intelektualny, kapitał rynkowy, kapitał zewnętrzny, zarządzanie kapitałem intelektualnym

\section{Wprowadzenie}

Wzmożone zainteresowanie kategorią kapitału intelektualnego w ostatnich latach wymaga identyfikacji tworzących go elementów. W literaturze najczęściej

\footnotetext{
Adres e-mail: karolina.beyer@usz.edu.pl
} 
przyjmuje się trójpodział kapitału intelektualnego na kapitał ludzki, organizacyjny i rynkowy. Przedmiotem rozważań w niniejszym artykule jest kategoria kapitału rynkowego.

Kapitał rynkowy odnosi się przede wszystkim do relacji organizacji z różnymi podmiotami znajdującymi się w otoczeniu. Kapitał rynkowy to również wiedza rynkowa będąca wynikiem relacji z klientami i dostawcami. Wielu menedżerów nie rozumie, jak wiele może uzyskać od swoich klientów i partnerów biznesowych (Akpinar, 2012). Zrozumienie tego, co klient oczekuje, jest pierwszym krokiem do sukcesu.

Kapitał rynkowy można podzielić na dwie kategorie: kapitał relacyjny określany jako relacje $\mathrm{z}$ klientami, dostawcami, partnerami, konkurentami i innymi interesariuszami oraz kapitał wyróżnienia związany m.in. z renomą marki, reputacją i wizerunkiem przedsiębiorstwa. Zarządzanie kapitałem rynkowym w głównej mierze będzie skupiało się na rozwijaniu pozytywnych relacji z podmiotami wchodzącymi w interakcje z przedsiębiorstwem i zaufania do nich. K.E. Sveiby (1997) zarządzanie strukturą zewnętrzną (kapitałem rynkowym) określa jako kształtowanie zewnętrznych przepływów wiedzy w relacjach z klientami i dostawcami.

\section{Kapitał relacyjny - kapitał klientów i kapitał partnerski}

Szczególną rolę w ramach kapitału rynkowego odgrywają relacje (kapitał relacyjny) $\mathrm{z}$ otoczeniem w postaci zasobów partnerskich i klienckich. Zasoby te uważane są za kluczowe dla organizacji, gdyż mają specyficzne cechy charakterystyczne dla zasobów niematerialnych, a mianowicie (Beyer, Szczepkowska, 2011):

- unikatowość,

- odporność na imitację i kopiowanie,

- brak możliwości zastąpienia ich innymi zasobami,

- dhugi czas potrzebny do ich wypracowania,

- łatwość zanikania, gdy nie są podtrzymywane,

- brak możliwości magazynowania,

- trudność wyceny,

- brak możliwości ochrony prawnej,

- możliwość jednoczesnego i wieloaspektowego wykorzystania w wielu miejscach.

Kapitał relacyjny jest pojęciem ściśle związanym z siecią relatywnych kontaktów przedsiębiorstwa $\mathrm{z}$ jego otoczeniem, tj. ze współpracującymi z nim innymi pod- 
miotami. Relacje te są często bardzo złożone i trudne do opisania, będąc unikalnym atrybutem danego przedsiębiorstwa.

W kształtowaniu kapitału relacyjnego, zarówno z klientami, jak i dostawcami czy innymi interesariuszami, wszelkie działania opierają się na wzajemnym zaufaniu, szacunku oraz często przyjaźni pomiędzy indywidualnymi osobami z powiązanych podmiotów. Ponieważ kapitał relacyjny opiera się zazwyczaj na osobistych kontaktach pracowników, należy starannie dobierać kadrę, która ma bezpośredni kontakt $\mathrm{z}$ klientami i innymi podmiotami. Aby w relacjach panowała atmosfera zaufania, odpowiedni pracownicy powinni charakteryzować się m.in. odpowiedzialnością, uczciwością, łatwością w nawiązywaniu kontaktów, a także przestrzegać obowiązujących w przedsiębiorstwie wartości (Kale, Singh, Perlmutter, 2000).

Wyzwaniem dla przedsiębiorstw w dzisiejszej rzeczywistości jest prawdziwe poznanie swoich klientów oraz ocena tego, jaki wkład w osiągnięcie celów korporacyjnych wniesie relacja z klientami. Kształtowanie relacji z klientami wymaga również zrozumienia dynamiki tego zasobu. Ponadto klienci generują najbardziej oczywistą i wymierną wartość w postaci środków pieniężnych płaconych za zakupione dobro czy usługę. Relacje z klientami obejmują m.in. zarządzanie marką, obsługę klienta oraz wiele innych ściśle powiązanych ze sobą aspektów funkcjonowania przedsiębiorstwa (Low, Kalafut, 2006).

N. Bontis (1998) uznaje, że najważniejszymi elementami kapitału klientów są wiedza na temat kanałów marketingowych oraz relacje z klientami. Natomiast K.E. Sveiby (2001) stwierdził, że organizacje oparte na wiedzy same wybierają swoich klientów, a nie odwrotnie. Klienci ci niekoniecznie wybierani są pod kątem wartości pieniężnych, które mogą wydać w przedsiębiorstwie, ale pod kątem wkładu, jaki mogą wnieść w formie intelektualnej.

W kształtowaniu kapitału klienckiego podstawą relacji z klientami jest zaspokajanie ich potrzeb w zakresie oferowanych im produktów i usług, z wykorzystaniem jakości, użyteczności, funkcji i możliwości czy też ceny. Lojalność klientów to ważny kapitał, dzięki któremu przedsiębiorstwo może osiągać korzyści.

Do utrzymywania kontaktów z klientami na najwyższym poziomie niezbędne jest korzystanie $\mathrm{z}$ wyspecjalizowanych systemów. Jednym z nim jest koncepcja CRM (Customer Relationship Management). Ma ona dwa podstawowe założenia (Szczygielska, 2009):

- pozyskanie nowego klienta jest o wiele droższe niż utrzymanie dotychczasowego (koszty mogą być nawet trzydziestokrotnie wyższe), 
- jedynie niektórzy klienci generują konkretne zyski, pozostała część klientów jest niedochodowa lub nawet może generować straty.

Zarządzanie relacjami z klientami powinno opierać się na gruntownych badaniach i monitorowaniu zapotrzebowania klientów, ich zwyczajów zakupowych oraz poglądów na temat przedsiębiorstwa i oferowanych produktów bądź usług.

Narzędziem wspierającym proces kształtowania kapitału klienckiego są bazy danych gromadzące wszelkie informację o klientach, ich upodobaniach, zadowoleniu, potrzebach itp. Bazy te muszą być systematycznie aktualizowane, aby cały czas dostarczać wartościowych informacji. Obecnie pozyskiwanie informacji o klientach jest rozbudowane na szeroką skalę, szczególnie w przypadku nowoczesnych przedsiębiorstw wykorzystujących do tego celu Internet. Każdy ruch internauty w sieci jest monitorowany. Informacje o odwiedzanych stronach, ich tematyce, wyszukiwanych słowach w Google i wszystko inne pozwala budować obraz klienta. Dzięki takim informacjom można klientowi zasugerować nowe produkty, usługi czy dobra komplementarne.

Zasoby klienckie stają się najważniejszym źródłem kreowania wartości przedsiębiorstwa, co wynika z następujących przesłanek (Dobiegała-Korona, 2009):

- klienci generują wpływy i rentowność, zapewniają płynność i wartość dodaną oraz rozwój przedsiębiorstwa,

- klienci zapewniają osiągnięcie celów wszystkich interesariuszy: właścicieli, pracowników, dostawców, partnerów i innych,

- klienci tworzą warunki stabilnego wzrostu i rozwoju przedsiębiorstw i gospodarek.

Należy podkreślić, że kapitał klientów kształtowany jest przez kapitał ludzki i organizacyjny i odwrotnie. Zależności te przedstawiono na rysunku 1.

Najniżej na rysunku znajdują się transakcje, w ramach których sprzedawca sprzedaje, a kupujący kupuje. W takiej sytuacji nabywca kieruje się zazwyczaj ceną przy wyborze dobra, nie kieruje nim lojalność do konkretnego sprzedawcy.

W sytuacji gdy nabywca oczekuje konkretnej specyfikacji danego produktu, będzie poszukiwał dostawcy, który tę specyfikację zagwarantuje. W tym przypadku następuje poszukiwanie pod kątem rozwiązań produktowych. By odnaleźć producenta/dostawcę itp. spełniającego oczekiwania, klient musi podzielić się pewną dozą informacji z dostawcą i na odwrót. W ten sposób powstanie pewna więź. 
Rysunek 1. Zależności pomiędzy kapitałem ludzkim, organizacyjnym i kapitałem klienta

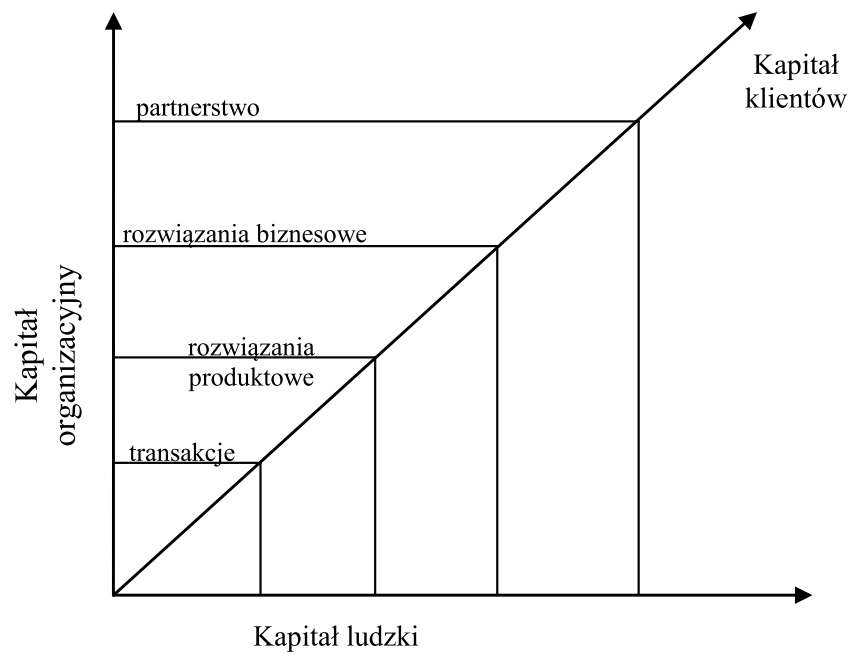

Źródło: opracowanie własne na podstawie Stewart (1999), s. 158.

Na poziomie rozwiązań biznesowych produkt stanowi drugie miejsce, wybierany jest na podstawie zaistniałych potrzeb bądź jako źródło naprawy problemu. W tej sytuacji kupujący i sprzedający muszą podzielić się dużą ilością informacji na temat zapotrzebowania i możliwość ich spełniania. Tworzący się związek na charakter bardziej trwały niż w poprzednim przypadku, gdyż z jednej strony kupujący chce wykorzystać doświadczenie sprzedającego, a z drugiej strony sprzedający chce utrzymać klienta. Należy podkreślić, że cena, jaką będzie płacił kupujący, będzie w zasadzie zapłatą za doświadczenie sprzedającego.

Najwyżej na wykresie znajduje się partnerstwo, w ramach którego dostawca/ sprzedający może przejąć zaspokajanie danej potrzeby w całości, np. poprzez stanie się partnerem czy dostawcą outsourcingu. Taka relacja sprzyja rozwojowi zarówno jednej, jak i drugiej strony. W tej sytuacji nie dochodzi do zawierania jednorazowej transakcji kupna-sprzedaży, lecz do zawarcia trwałego, długoterminowego kontraktu przynoszącego korzyści każdej ze stron.

Kolejnym bardzo istotnym działaniem w zakresie kształtowania kapitału relacyjnego, a tym samym kapitału rynkowego przedsiębiorstwa, jest kształtowanie kapitału partnerskiego. Kapitał partnerski polega na tworzeniu korzystnych stosunków pomiędzy przedsiębiorstwem a innymi zainteresowanymi podmiotami (dostawcy, partnerzy, kooperanci, inwestorzy i inni). Spośród związków z innymi przedsię- 
biorstwami wyróżnić można relacje o charakterze kooperacyjnym i koncentracyjnym. Zarówno pierwsze, jak i drugie zawierane są po to, by zwiększyć potencjał i konkurencyjność każdej ze stron. Związki kooperacyjne to współpraca podmiotów w ramach łączących je umów, porozumień czy kontraktów. Współpraca ta może mieć charakter krótkoterminowy lub być kooperacją długoterminową, strategiczną. Najczęściej spotykaną formą jest kooperacja w ramach aliansów strategicznych, które umożliwiają podmiotom dzielenie się wiedzą, doświadczeniem, technologią, kanałami dystrybucji itp. (Gierszewska, Olszewska, Skonieczny, 2013). Kształtowanie kapitału partnerskiego może również być realizowane poprzez działania związane z licencjonowaniem i franchisingiem (Janasz, 2010).

Oprócz wspomnianych sposobów kooperacji wartościowe dla przedsiębiorstwa są również inne umowy i kontrakty o charakterze wyróżniającym. Takie, które zagwarantują przedsiębiorstwu uzyskanie unikatowej pozycji. Związki o charakterze koncentracyjnym są bardzo ścisłe, w ich ramach dochodzi albo do utraty odrębności ekonomicznej i prawnej podmiotu, albo następuje podległość pod jednolite kierownictwo. Koncentracja przedsiębiorstw realizowana jest poprzez fuzje i przejęcia. Połączenie bądź przejęcie innego podmiotu sprawia, że możemy stać się właścicielami unikatowych zasobów kapitału intelektualnego takiego przedsiębiorstwa. Dokonując fuzji lub przejęcia, pozyskuje się nie tylko majątek fizyczny i finansowy, które pozwalają zwiększyć potencjał gospodarowania, a zwłaszcza zasoby niematerialne, jak np. pracowników i ich wiedzę, systemy i infrastrukturę organizacyjną, wiedzę organizacji, unikatowe know-how, lojalnych klientów, sieci dystrybucji itp.

Przewaga konkurencyjna, jaka wynika z posiadania sieci wartościowych relacji z partnerami, pochodzi z następujących źródeł (Głuszek, 2004):

- inwestowania w wyróżniające, specyficzne zasoby, w celu pogłębiania wzajemnych relacji,

- realizowania procesu wymiany wiedzy, co sprzyja uczeniu się,

- łączenia komplementarnych lub rzadkich zasobów i umiejętności, co w konsekwencji umożliwia tworzenie nowych unikatowych technologii, produktów lub usług,

- obniżania kosztów w wyniku wykorzystywania bardziej efektywnych sposobów gospodarowania.

Należy podkreślić, że wszelkie relacje między partnerami opierają się na wzajemnym zaufaniu, które zapewnić ma bezpieczeństwo, że żadna ze stron nie wykorzysta słabości partnera. Kształtowanie pozytywnych relacji z partnerami przynosi wiele korzyści, przede wszystkim generuje nową wiedzę i pozwala się uczyć od nich. 


\section{Kapitał wyróżnienia}

Poza kształtowaniem relacji z otoczeniem wpływ na kapitał rynkowy mają elementy wyróżnienia takie jak image, reputacja, marka, wizerunek itp. Współczesne przedsiębiorstwo chcące odnieść sukces rynkowy musi dbać o wizerunek, reputację swoją i swojej marki. Za dbanie o wizerunek odpowiadają wszyscy pracownicy, ale niezbędne są również działania ze strony wyspecjalizowanych jednostek odpowiedzialnych za public relations (PR), które umożliwia kreowanie obrazu przedsiębiorstwa zarówno dla klientów wewnętrznych, jak i zewnętrznych oraz innych podmiotów zainteresowanych (Perechuda, 2005).

Reputacja jest specyficznym zjawiskiem, które może być omawiane w kategorii produktu i przedmiotu konkurencji. Jest wynikiem wdrażania unikatowości, która odróżnia przedsiębiorstwo od jego rywali. Reputacja to rodzaj informacji dla klientów, pracowników, inwestorów, a nawet dla całego społeczeństwa. Stanowi zbiór osobistych opinii związanych z solidnością, odpowiedzialnością, zaufaniem i wiarygodnością przedsiębiorstwa. Reputacja może dotyczyć przedsiębiorstwa i produktu.

Reputacja przedsiębiorstwa często związana jest z pojęciami takimi jak tożsamość lub image firmy, a reputacja produktu identyfikowana jest z marką i znakiem towarowym. Różnica pomiędzy tożsamością a imagem przedsiębiorstwa polega na tym, że tożsamość jest obrazem firmy widzianym przez nią samą, natomiast image jest obrazem firmy widzianym przez otoczenie.

Wspomniana już wcześniej marka definiowana jest z jednej strony jako nazwa, symbol, znak graficzny itp. (jako znak towarowy), z drugiej zaś - jako zespół cech związanych z przeświadczeniem konsumentów o korzyściach wynikających z użytkowania produktu. Marka może dotyczyć produktu, usługi lub całego biznesu. Wypracowanie marki jest procesem długotrwałym i wymaga m.in. wysokich nakładów na marketing. Zważywszy jednak na fakt, że klienci mają wiele rynkowych możliwości wyboru, pojęcie marki nabiera dużego znaczenia. Marka jest tym elementem, który pozwala z jednej strony przedsiębiorstwu wyróżnić się na tle konkurencji, z drugiej zaś jest narzędziem pomagającym klientom podjąć decyzje o wyborze właściwego produktu czy usługi. Marka może być również definiowana jako przyrzeczenie dostarczenia zestawu konkretnych korzyści, jakości i specyficznych cech. Należy podkreślić, że marka ma istotny wpływ na image i tożsamość przedsiębiorstwa i odwrotnie. Aby marka przynosiła korzyści i spełniała swoją rolę, powinna byś nieustannie kształtowana m.in. poprzez działania marketingowe. Wypracowanie dobrej marki wymaga wiele czasu, dlatego niezbędne jest podtrzymywanie i wzmacnianie jej pozycji. 


\section{Podsumowanie}

Kapitał rynkowy obok kapitału ludzkiego i organizacyjnego jest elementem kapitału intelektualnego. Kapitał rynkowy składa się z jednej strony z kapitału relacyjnego określanego przez relacje z klientami i partnerami, a z drugiej strony z kapitału wyróżnienia określanego przez reputację, markę, image, wizerunek itp. Wszystkie elementy kapitału rynkowego są ze sobą ściśle związane. To, czy przedsiębiorstwo będzie wyróżniać się na arenie rynkowej, ma związek z występującymi relacjami z klientami i partnerami. To, jak przedsiębiorstwo odbierane jest przez otoczenie, będzie również zależało od tego, jaki ma kapitał ludzki i organizacyjny, czyli od pozostałych elementów kapitału intelektualnego.

Proces kształtowania poszczególnych komponentów kapitału rynkowego ma na celu zapoznanie otoczenia $\mathrm{z}$ organizacją i odwrotnie. W związku z tym organizacja musi podejmować wiele działań, by kształtować relacje z klientami i dostawcami, a poprzez te i inne działania dbać o wizerunek, reputację marki i całego przedsiębiorstwa. Podejmowane działania w tym zakresie powinny być skoncentrowane na pozyskiwaniu jak najwięcej wiedzy z otoczenia.

Podsumowując, współczesne przedsiębiorstwa dążące do osiągania sukcesów rynkowych powinny podejmować działania m.in. w zakresie kształtowania kapitału rynkowego, dzięki czemu wzrastać będzie wartość kapitału intelektualnego, a tym samym wartość całego przedsiębiorstwa.

\section{Literatura}

Akpinar, A.T. (2012). Intellectual Capital. Pobrane z: http://www.opf.slu.cz/vvr/akce/turecko/pdf/Akpinar.pdf.

Beyer, K., Szczepkowska, M. (2011). Gospodarowanie zasobami niematerialnymi. W: S. Marek, M. Białasiewicz (red.), Podstawy nauki o organizacji. Przedsiębiorstwo jako organizacja gospodarcza (s. 148-189). Warszawa: PWE.

Bontis, N. (1998). Intellectual capital: an exploratory study that develops measures and models. Management Decisions, 36 (2), 63-76.

Dobiegała-Korona, B. (2009). Klient jako kapitat przedsiębiorstwa. W: I. Lichniak (red.), Nauka o przedsiębiorstwie. Wybrane zagadnienia. Warszawa: Oficyna Wydawnicza SGH.

Gierszewska, G., Olszewska, B., Skonieczny, J. (2013). Zarzadzanie strategiczne dla inżynierów. Warszawa: PWE.

Głuszek, E. (2004). Zarzadzanie zasobami niematerialnymi przedsiębiorstwa. Wrocław: Wydawnictwo Akademii Ekonomicznej we Wrocławiu. 
Janasz, K. (2010). Kapitał w finansowaniu działalności innowacyjnej przedsiębiorstw w Polsce. Źródła i modele. Warszawa: Difin.

Kale, P., Singh, H., Perlmutter, H. (2000). Learning and Protection of Proprietary Assets in Strategic Alliances: Building Relational Capital. Strategic Management Journal, 21 (3), 217-237.

Low, J., Kalafut, P.C. (2006). Niematerialna wartość firmy. Kraków: Wolters Kluwer.

Perechuda, K. (2005). Bariery dyfuzji wiedzy w przedsiębiorstwach. W: E. Niedzielska, H. Dudycz, M. Dyczkowski (red.), Nowoczesne technologie informacyjne w zarzadzaniu (s. 226-230). Wrocław: Wydawnictwo Akademii Ekonomicznej we Wrocławiu.

Stewart, T.A. (1999). Intellectual Capital. The New Wealth of organizations. New York: Doubleday.

Sveiby, K.E. (1997). The New Organizational Wealth. San Francisco: Berrett-Koehler Publishers.

Sveiby, K.E. (2001). A knowledge-based theory of the firm to guide in strategy formulation. Journal of Intellectual Capital, 2 (4), 344-358.

Szczygielska, A. (2009). Kapitat intelektualny w gospodarce opartej na wiedzy. Wrocław: Wydawnictwo Uniwersytetu Ekonomicznego we Wrocławiu.

\title{
MARKET CAPITAL IN THE CONCEPT OF INTELLECTUAL CAPITAL
}

\begin{abstract}
Market capital as well as human capital and organizational capital is one of the elements of intellectual capital in enterprises. The success of today's business depends on a proper and effective management of intellectual capital, that is why it is necessary to understand the essence of its individual elements. Market capital is usually called as "external capital" and is defined as the relationship with the external environment, mainly with customers, but also with suppliers, partners and competitors. An external capital is also related with business reputation, image and customer loyalty. The market capital creates enterprise value through appropriate contacts with its surroundings and it stems from the involvement of human capital, which is supported by organizational capital of an organization.

The article is theoretical in nature, and its main purpose is to present the essence of an external capital and its components, as well as to present their impact on the intellectual capital of an organization.
\end{abstract}

Keywords: market capital, external capital, intellectual capital, intellectual capital management

JEL codes: D24, M19, M49 